\title{
調查報告
}

\section{企業における健康施策決定プロセスと企業・労働者のニーズを 踏まえた産業医の介入に関する探索的検討}

\author{
新里 なつみ, 永田 昌子, 永田 智久, 森 晃爾
}

産業医科大学産業生態科学研究所産業保健経営学研究室

抄録：目的：本研究では, 企業における健康施策決定プ ロセスと企業・労働者のニーズを踏まえた産業医の介入 に関する実態を調査することで，健康施策において企業 の意思決定が円滑になされるための産業保健サービスの 要素・手法を探索的に調査・検討した．方法：企業にお ける健康施策の立案に関与する 10 社11名の産業医を機縁 法にて選定し，半構造化面接を実施した. Berelson, B.の 内容分析に基づき質的帰納的に分析した。結果 : 本研究 のテーマに対応した144カテゴリが形成され，社内健康施 策の意思決定プロセス・産業医の介入・産業医の介入に 関する補足要素の 3 要素に整理された。このうち産業医 の介入は,「関係性の構築・相互理解の促進」,「根回し 調整」,「仮説に基づくニーズの可視化」,「統合的な企画 づくり・提案」の 4 要素に関連する具体的な介入手法が 示された. 考察 : 企業の意思決定が円滑になされるため の産業保健サービスの要素・方法として，1）健康施策 における企業の意思決定の特徴や意思決定者の前提を踏 まえて，合意形成を要する範囲やその影響を把握するこ とや， 2 ）産業保健への認識を高めるために, 恒常的に 産業保健に関する情報を経営情報へ翻訳しながら, 提案 を行うことが有効であると考えられた，産業医を中心と した産業保健専門職は, 本研究にて明らかとなった手法 を, 活動の自己評価や改善に活用し, 健康施策決定に貢 献することが望まれる.

(産衛誌 2019; 61(5): 141-158)

doi: 10.1539/sangyoeisei.2018-038-E

2018年11月 7 日受付；2019年 3 月 1 日受理

J-STAGE 早期公開日：2019年 3 月22日

連絡先 : 新里なつみ $\overline{7} 807-8555$ 福岡県北九州市八幡西区医 生ヶ丘1-1 産業医科大学産業生態科学研究所産業保健経営学研 究室

Correspondence to: Natsumi Shinzato, Department of Occupational Health Practice and Management, University of Occupational and Environmental Health, 1-1 Iseigaoka Yahatanishi-ku, Kitakyushu 807-8555, Japan

(e-mail : n-shinzato@med.uoeh-u.ac.jp)
キーワード : Organizational decision-making, Health promotion, Occupational health physicians, Intervention, Needs of companies, Needs of workers

\section{I. はじめに}

産業保健専門職は, 事業場において労働者の健康確保 のために, 健康診断や保健指導, 健康教育, 職場復帰支 援など様々な産業保健サービスを提供している。 その際, 産業保健専門職は, 労働者の健康課題を評価し, 各企業 の実状に適した産業保健サービスを提供する必要がある. 施策実施には費用負担や労働者へ向けた調整が必要であ り，場合によっては社内ルールの整備を図る場合もある ことから, 提案について経営者等の理解を得て意思決定 される必要がある。 そして, 意思決定者への説明等, 意 思決定プロセスへの介入についても，産業保健サービス の提供とともに, 産業保健専門職の重要な役割と考えら れる。

組織とは情報の授受を媒介とする分権化された意思決 定のシステム， かつ相互関係をもつ役割のシステム ${ }^{1)}$ あり, 多くの企業で, それぞれの特徵に合った意思決定 システムが存在する. 産業保健サービスについても, 企 業の意思決定システムに沿いながら体系的に計画・立案 され ${ }^{2)}$, 経営者の意思決定を引き出す必要がある. その ためには, 産業保健専門職が意思決定者への情報提供や その他のプロセスに留意し, 相互関係を基本とした意図 的な介入を行い, 企業活動に必要なサービスとして経営 者に価値を認められる必要がある ${ }^{3)}$.さらにその前提と して，意思決定者である経営者やサービスの受け手であ る労働者の産業保健サービスに対するニーズを把握し, 施策に反映させることが重要である ${ }^{4)}$. その結果, 意思 決定者や労働者の産業保健サービスに対する満足度を向 上させ, 産業保健サービス全体の価值認識の向上が期待 できると考えられる。しかし，過去の調査研究において 産業保健サービスに関する企業の意思決定プロセスや, その意思決定プロセスに対応した産業保健専門職の具体 
的な介入方法に関する分析結果の報告はない. 蔦木 ${ }^{5)}$ と 畑中 ${ }^{6}$ は, 産業保健分野の組織への支援プロセスに関す る研究を行っているが, 企業の意思決定プロセスについ ては重点を置いていない。また，蔦木 ( $^{5}$ は保険組合の保 健師という立場であり, 畑中 ${ }^{6)}$ は保健師と管理監督者と の関係形成という，限定された内容である.

加えて経営者および労働者の産業保健サービスに対す るニーズに関して, 田澤7) や福田 ${ }^{8)}$, 黑木 ${ }^{9)}$ らが調查報告 を行っているものの, ニーズに基づく意思決定プロセス や専門職の介入について言及した研究は少ない.

一方, 組織の意思決定については, 経営学を中心とし た他分野において，様々な検討が行われている。まず組 織成員の意思決定には必要な情報を集め, 情報から案を 作成・列挙し，選択する過程が含まれている 示されている，ただし不確実性の下では人間の合理性に は常に限界がある ${ }^{11}$ ことから, 最適とされる選択ではな く自己が満足できる選択に基づいて意思決定が行われて いると考えられている. 加えて決定前提という, 意思決 定に执いて結論に影響を及ぼす前提が存在し，その前提 には意思決定者の価値観や意思決定者が認識した事実, 知識等が含まれることが明らかとなっている.

そこで，他分野に扔ける知見を参考として，企業にお ける健康施策決定プロセスと, 経営者拉よび労働者の産 業保健サービスに対するニーズ把握に着目した産業医の 介入に関する実態調査を行い，産業保健サービスに対す る意思決定が円滑になされるための産業医の介入の要素 および具体的な手法について, 探索的に検討することを 目的とした研究を行った。

\section{II. 用語の定義}

本論文で用いられる用語について，以下の通り定義し た。

「意思決定者」：実質的に健康施策を最終承認する立場の 者

$\lceil$ 「キーパーソン」：意思決定者を含む健康施策の決定に影 響を与える立場の者

「介入」: 健康施策決定に影響を与える要因の有無または 程度を制御する意識的な行為

「決定前提」: 意思決定に扔いて結論に影響を及ぼす前提. 決定前提は価値的・倫理的な要素の価值前提と, 事実 的・判断的な要素の事実前提に分けられる.

「ニーズ」: 産業保健専門職が医学的必要性やトレンドを 加味し判断した必要性. ただし, 本研究の半構造化面 接で用いた質問では, デマンド（対象の顕在化した要 求) がニーズに含まれている.

「ウォンッ」: ニーズを具体的に示した欲求

\section{III. 方 法}

\section{1. 研究対象}

企業における健康施策の立案に関与していること, 企 業や事業場のトップまたは産業保健施策の実質的な意思 決定者と日常的なコミュニケーションがあることを条件 に，研究に同意が得られた産業医を機縁法にて選定した。 収集した結果をインタビュー実施期間中に適宜チェック し, 質的研究の経験がある産業保健師の著者と, 産業医 学を専門とし, 質的研究の経験がある研究者 3 名 (共著 者）において理論的飽和と判断した段階でデー夕収集を 終了とした.

2. 研究期間

2017年 9 月～2018年 8 月

3. インタビュー調査

30分〜 1 時間の半構造化面接（個人面接法）を $1 \sim 2$ 名の質的研究経験者（著者及び共著者）によりインタ ビューガイドを用いて各 1 回実施した. インタビュー場 所は産業医科大学内及び近隣の会議室を設定した。イン タビュー記録は，インタビュイー承諾の下にICレコー ダーにて録音し，後日逐語録を作成した。

\section{4. 質問の枠組み}

組織的な意思決定プロセスについては，企業ごとの多

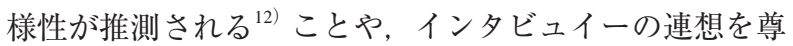
重したいことから，自由度の高い質問項目を設定した。 なお，企業の健康推進体制図 ${ }^{13-16)}$ を参考にプロセスを説 明しやすくするための補足質問を追加した，産業医の介 入については, 意思決定には意思決定者の価值前提 ${ }^{1}$ が 影響し，かつ企業ごとに意思決定の構造に合わせた多面 的な情報が共有される可能性から, 情報共有の内容を問 う項目を設定した，更に，意思決定者および労働者の ニーズを施策へ反映させることが, 円滑な意思決定へ繋 がると仮定し，ニーズの把握方法・場面に関する独立し た項目を設定した。

その結果，まず以下の 6 項目を用意した.

(1)社内での健康施策決定に至るまでのプロセスはどのよ うになっているか.

（通さなければいけない人や会議体は何か，どのような 流れか)

(2)プロセスの中で産業保健専門職として介入する場面や 方法 (・コッ) は何か.

(3)意思決定者が関心のある情報，共有している情報は何 か.

（4)意思決定者と共有できない情報はあるか，その理由は 
何か.

(5)意思決定者のニーズの把握はどのように行っているか.

(6)労働者のニーズの把握はどのように行っているか.

なお，質問を行う前には，インタビュイーに対し，過 去に「新たな健康施策を自ら展開した，もしくは施策展 開に関与した事例」を想定するよう伝えた上でインタ ビューを実施した。そして, データ収集・分析の過程で 枠組みの再検討を行った結果, 情報の共有内容やニーズ 把握以外の介入要素も多く発言されたため,「(1)- (6)以外 で意思決定者を納得させる資源は何か」を追加し，最終 的に計 7 項目を質問項目とした。

\section{5. デー夕分析}

逐語録にまとめたインタビュー内容は，1 文脈単位に 分けて記録単位とし Berelson, B. の内容分析 ${ }^{17)}$ に基づき 質的帰納的に分析した。意味内容の類似性に基づきカテ ゴリを導き出した。 質問項目 (2)(7)から得られた要素は, 情報の共有やニーズの把握を除いた産業医の介入を未分 類で集合させたものであるため，産業医の介入において 主要な要素となる大項目の再分類を行った。意思決定者 に関する回答では意思決定関与者に関わる要素が多いこ とから総じてキーパーソンとして整理することとした.

\section{6. カテゴリ信頼性の確認}

著者と, 産業医学を専門とし質的研究の経験をもつ研 究者 3 名（共著者）によるカテゴリ分類への一致率を Scott.W.A の式 ${ }^{17)}$ に基づき算出し，検討した. 3 名それ ぞれで，著者のカテゴリ分類結果との一致率が70\%を超 えるまでカテゴリの再構築及びカテゴリ信頼性確認の手 続きが繰り替えされた.

\section{7. 結果の図解化}

インタビューから得られた要素を, 著者及び産業医学 を専門とする複数の研究者（共著者 3 名含む）により再 構築したカテゴリを図解化した。

\section{8. 倫理的配慮}

対象者には研究協力依頼書を用いて口頭で研究目的, 方 法, 倫理的配慮（個人が特定されないよう情報管理を行 う）を説明し, 同意書への署名によって研究参加意思を確 認した. なお, 本研究は, 研究者が所属する機関の倫理審 査委員会の承認（2017年 8 月 2 日）を得て実施した。

\section{IV. 結 果}

\section{1. 対象者の概要}

インタビューは理論的飽和と判断された時点で終了と した. 最終的に10社11名（男性 7 名, 女性 4 名）を対象 とした，産業医の経験年数は1.5年～18年, 関与する対象 企業の従業員数は, 最小約 50 名, 最大約 13,000 名, 所在 地は関東 2 事業所, 関西 2 事業所, 九州 7 事業所であり, 業種は製造業, 販売業, 鉄鋼業, 鉄道業であった. 産業 医が日常的に関与する重要な人物は, 意思決定者のみで なく，複数の意思決定関与者を含んでいた. 介入対象と なる主なキーパーソンは職位が様々であった（Table 1).

2. 分析されたカテゴリ

11名のインタビュー内容は862記録単位に分類できた. このうち342記録単位は抽象的もしくは研究テーマから逸 脱した内容であったため除外し，520単位を分析対象とし た. 大項目ごとの分析対象単位数を Table 2 に示す.

分析対象の記録単位を意味内容の類似性に基づき分類 した結果, 本研究のテーマに対応した144カテゴリが形成

Table 1. インタビュイーの属性

\begin{tabular}{|c|c|c|c|c|c|c|c|c|}
\hline \multirow[b]{2}{*}{ 企業 } & \multirow[b]{2}{*}{ 地域 } & \multirow[b]{2}{*}{ 業種 } & \multirow{2}{*}{$\begin{array}{c}\text { 対象 } \\
\text { 従業員数 }\end{array}$} & \multirow{2}{*}{$\begin{array}{c}\text { 介入対象となるキーパーソン } \\
\text { (意思決定者および関与者) }\end{array}$} & \multicolumn{4}{|c|}{ インタビュイー } \\
\hline & & & & & $\begin{array}{l}\text { 産業 } \\
\text { 医歴 }\end{array}$ & $\begin{array}{l}\text { 年齢 } \\
\text { (年代) }\end{array}$ & 性別 & $\begin{array}{c}\text { 産業衛生 } \\
\text { 専門医 }\end{array}$ \\
\hline A & 九州 & 化学工業 & 1,200 & 事業所長·関連事業部長 · 課長 & 6 & 30 & 女 & $\bigcirc$ \\
\hline B & 九州 & 電子部品開発製造業 & 2,800 & 事業所長‧総務部長‧課長 & 5 & 30 & 女 & $\bigcirc$ \\
\hline $\mathrm{C}$ & 九州 & 商品小売業 & 50 & 社長 & 10 & 30 & 女 & $\bigcirc$ \\
\hline $\mathrm{D}$ & 関東 & 産業車製造業 & $1,500 \sim 2,000$ & 工場長 · 安全関連部担当者 & 4 & 30 & 男 & $\bigcirc$ \\
\hline $\mathrm{E}$ & 関東 & 製鉄業 & 2,200 & 事業所長・安全関連室長 & 1.5 & 20 & 女 & \\
\hline $\mathrm{F}$ & 九州 & 自動車製造·販売業 & 3,500 & 社長 · 工場長 · 労働組合 · 総務人事部長 & 10 & 40 & 男 & $\bigcirc$ \\
\hline$F^{\prime}$ & 関西 & 自動車製造・販売業 & 13,000 & 社長‧各事業本部‧総務人事部長 & 8 & 40 & 男 & $\bigcirc$ \\
\hline G & 九州 & 鉄道業産業医 & 8,300 & 社長・常務・人事部長 & 12.5 & 40 & 男 & $\bigcirc$ \\
\hline $\mathrm{H}$ & 九州 & 精密機器製造販売業 & 1,500 & 健康保険組合の常務理事 & 4 & 40 & 男 & $\bigcirc$ \\
\hline I & 関西 & 電気機器製造業 & 6,000 & 安全関連事業部 - 統括産業医 /人事部長 - 課長 & 18 & 40 & 男 & $\bigcirc$ \\
\hline $\mathrm{J}$ & 九州 & 製造業 & 100 & 安全管掌役員‧人事部長・室長（産業医） & 18 & 40 & 男 & $\bigcirc$ \\
\hline
\end{tabular}


Table 2. 大項目ごとの分析対象単位数

\begin{tabular}{llr}
\hline \multicolumn{1}{c}{ 要素 } & \multicolumn{1}{c}{ 大項目 } & 分析対象単位※ \\
\hline 社内健康施策の意思決定プロセス & 社内健康施策の意思決定プロセス & 132 \\
\hline 産業医の介入 & 関係性の構築・相互理解の促進 & 114 \\
& 根回し・調整 & 32 \\
& 仮説に基づいたニーズの可視化 & 61 \\
& 統合的な企画づくり・提案 & 25 \\
\hline 産業医介入の補足要素 & 共有される情報 & 128 \\
& 接触場面 & 37 \\
& 産業医介入の阻害要因 & 19 \\
\hline 全体 & & 520 \\
\hline
\end{tabular}

※ 1 単位に異なる大項目が重複している場合があるため, 全体の単位数と各大項目の単位数の 合計は一致しない

Table 3a. 分析されたカテゴリ（2-1. 社内健康施策の意思決定プロセス）

\begin{tabular}{|c|c|}
\hline & 社内健康施策の意思決定プロセス（2-1） \\
\hline $\begin{array}{l}\text { キーパーソンの意思決定 } \\
\text { への影響因子 }\end{array}$ & $\begin{array}{l}\text { 経営者の価值観・企業のポリシーやミッション } \\
\text { 意思決定者・身近な人の健康問題に関連するテーマ } \\
\text { 扱う課題テーマの種類・規模 } \\
\text { 社内外で発生した事例の距離感 }\end{array}$ \\
\hline $\begin{array}{l}\text { キーパーソンとの } \\
\text { 合意形成 }\end{array}$ & $\begin{array}{l}\text { 身近な利害関係者との合意形成 } \\
\text { 所属事業部・事業所責任者との合意形成 } \\
\text { 安全健康管掌役員との合意形成 } \\
\text { 関連部署との合意形成 } \\
\text { 労働組合との合意形成 } \\
\text { 意思決定者との合意形成・承認 }\end{array}$ \\
\hline 承認形式 & $\begin{array}{l}\text { 協議・審議を目的とした会議で最終承認 } \\
\text { 報告を目的とした会議で最終承認 } \\
\text { 合議制 } \\
\text { 複数単独執行制 } \\
\text { 意思決定者と直接交渉で最終承認 } \\
\text { 会議前に実質的に承認済み } \\
\text { 意思決定プロセスが決まっているか否か }\end{array}$ \\
\hline $\begin{array}{l}\text { キーパーソンを決定する } \\
\text { 影響因子 }\end{array}$ & $\begin{array}{l}\text { 承認機能をもつレイヤー（経営層か否か） } \\
\text { 産業保健職自身の所属（健保兼務等） } \\
\text { 勤務場所（本社と支店／エリア／系列会社） } \\
\text { 資金源（事業所／工場／本社／支店） } \\
\text { 労働組合の有無 }\end{array}$ \\
\hline $\begin{array}{l}\text { キーパーソンとの } \\
\text { 関係性への影響因子 }\end{array}$ & $\begin{array}{l}\text { 意思決定者へのアクセスのしやすさ（距離等） } \\
\text { 最終的な承認の場に介入するか否か }\end{array}$ \\
\hline
\end{tabular}

された．形成されたカテゴリは，社内健康施策の意思決 定プロセス，産業医の介入，産業医の介入に関する補足 要素の 3 要素に整理され，7つの大項目および20の中項 目に分類された。社内健康施策の意思決定プロセスの要 素に分類される大項目は【社内健康施策の意思決定プロ セス】の 1 項目, 産業医の介入については【関係性の構
築・相互理解の促進】【根回し・調整】【仮説に基づいた ニーズの可視化】【統合的な企画づくり・提案】の 4 項 目, 産業医介入の補足要素については【共有される情報】 【接触場面】【産業医介入の阻害要因】の 3 項目に分類さ れた. 3 要素それぞれ分析・分類されたカテゴリを表に 示す (Table 3a, 3b, 3c). 
Table 3b. 分析されたカテゴリ（2-2． 産業医の介入）

\begin{tabular}{|c|c|c|c|c|c|}
\hline \multicolumn{6}{|c|}{ 産業医の介入（要素と具体的な方法）（2-2） } \\
\hline \multicolumn{3}{|r|}{ 1）関係性の構築・相互理解の促進 } & \multicolumn{3}{|r|}{ 2）根回し・調整 } \\
\hline \multirow{7}{*}{$\begin{array}{c}\text { 接触機会の } \\
\text { 獲得 }\end{array}$} & 意識 & キーパーソンと頻回に接触機会をもつ & \multirow{2}{*}{$\begin{array}{l}\text { 環境を } \\
\text { つくる }\end{array}$} & 意識 & やらざる得ない環境を整える（外堀を埋める） \\
\hline & 行動 & 業務外 (宴席等) でのコミュニケーション & & 行動 & 新たな会議体の設定で介入機会を増やす \\
\hline & 行動 & キーパーソンと人を介さず連絡をとる（メール・手紙・電話等 $)$ & \multirow{4}{*}{$\begin{array}{c}\text { 人を } \\
\text { おさえる }\end{array}$} & 意識 & 会社の承認ルート（人）を把握する \\
\hline & 行動 & キーパーソンの活動に同行する & & 行動 & 関連部署・関連事業所を調整する（説得含む） \\
\hline & 行動 & 産業保健活動以外の社内活動に参加する & & 行動 & 審議・決定の前段階にキーパーソンへの根回しを行う \\
\hline & 行動 & 意思決定者に直接会いに行く & & 行動 & 通常業務以外の社内活動に参加して顔を売る \\
\hline & 行動 & こまめに新たな情報を伝えに行く & & & \\
\hline \multirow{10}{*}{$\begin{array}{c}\text { 信頼性の } \\
\text { 保持 }\end{array}$} & 意識 & キーパーソンとの活動内容・状況の相互理解 & & & \\
\hline & 意識 & キーパーソンとの信頼される関倸性を構築する & & & \\
\hline & 意識 & 心理的距離を縮めるように関わる & & & \\
\hline & 意識 & キーパーソンのキャラクターに合わせて関わる & & & \\
\hline & 行動 & 活動に対して第三者からの良い評価を得る & & & \\
\hline & 行動 & 活動を後押しする仲間を増やす & & & \\
\hline & 行動 & キーパーソンに手柄を渡す & & & \\
\hline & 行動 & 日頃から引き出しを持ち, 求められたときに期待に応える & & & \\
\hline & 行動 & キーパーソンに役に立つと思わせる（ポジショニング） & & & \\
\hline & 行動 & 産業保健職個人に興味をもってもらう & & & \\
\hline \multirow{5}{*}{$\begin{array}{c}\text { 活動や課題 } \\
\text { の共有 }\end{array}$} & 意識 & 問題意識を持たせる・方向性を合わせる & & & \\
\hline & 行動 & 施策に関連する背景や経過を段階的に伝える（布石を置く） & & & \\
\hline & 行動 & キーパーソンと一緒に考える機会をもつ & & & \\
\hline & 行動 & キーパーソンと成功体験を共有する & & & \\
\hline & 行動 & 活動状況をキーパーソンと共有できる既定の場・時間を利用する & & & \\
\hline
\end{tabular}

\begin{tabular}{|c|c|c|c|c|c|c|}
\hline \multicolumn{4}{|r|}{ 3）仮説に基づいたニーズの可視化 } & \multicolumn{3}{|r|}{ 4）統合的な企画づくり・提案 } \\
\hline \multirow{13}{*}{$\begin{array}{l}\text { ニーズ } \\
\text { 仮説 }\end{array}$} & \multirow{7}{*}{$\begin{array}{c}\text { 労働者・現場 } \\
\text { との関わり }\end{array}$} & 意識 & 労働者と接点も持つ時は常に意識する & \multirow{7}{*}{$\begin{array}{l}\text { 統合的な } \\
\text { 企画づくり }\end{array}$} & 意識 & 日頃から引き出しを準備する \\
\hline & & 行動 & 産業保健活動で対面した労働者の反応をみる & & 意識 & 情報を視覚化する \\
\hline & & 行動 & 労働者から直接受けた要望から推測する & & 意識 & 文書でまとめる \\
\hline & & 行動 & 産業保健職の現場感から推測する & & 行動 & 費用面も含めて年間計画を立案する \\
\hline & & 行動 & 健診問診データから推測する & & 行動 & 外部の情報を活用して施策をつくる \\
\hline & & 行動 & 社内イベントに参加して情報収集する & & 行動 & 予算の範囲内で有効な施策をつくる \\
\hline & & 行動 & 組合からの情報から推測する & & 行動 & 徐々に目標を上げる \\
\hline & \multirow{6}{*}{$\begin{array}{c}\text { キーパーソン } \\
\text { との関わり }\end{array}$} & 意識 & 興味がないものも注目して分類する & \multirow{8}{*}{$\begin{array}{l}\text { 統合的な } \\
\text { 企画提案 }\end{array}$} & 意識 & 根気強く企画を提案し続ける \\
\hline & & 行動 & キーパーソンから直接くる要望や質問から推測する & & 意識 & 企業全体にとってのメリットを伝え後押しをする \\
\hline & & 行動 & キーパーソンとの日常会話や会誐等での指摘から推測する & & 行動 & 社内外の動きと関連づけた案を提示する \\
\hline & & 行動 & キーパーソンの活動に同行する & & 行動 & 施策に関するプレゼンテーションを行う \\
\hline & & 行動 & キーパーソンの部下から聴取する & & 行動 & 聴取したニーズと分析データを併せて提示する \\
\hline & & 行動 & 情報共有・企画提案後の意思決定者の反応をみる & & 行動 & ニーズに適した資源を複数提案する \\
\hline \multirow{14}{*}{$\begin{array}{l}\text { ニーズ } \\
\text { の } \\
\text { 可視化 }\end{array}$} & \multirow{4}{*}{$\begin{array}{c}\text { 労働者・現場 } \\
\text { との関わり }\end{array}$} & 行動 & 労働者との接触時に困りごとを尋ねる & & 行動 & トライアル施策を提案する \\
\hline & & 行動 & 現場から業務の依頼を受けた時にヒアリングする & & 行動 & 公平性を利用して施策展開につなげる \\
\hline & & 行動 & 職場上司・衛生担当者から情報収集する & & & \\
\hline & & 行動 & アンケート調查をする & & & \\
\hline & \multirow{10}{*}{$\begin{array}{l} \\
\text { キーパーソン } \\
\text { との関わり }\end{array}$} & 意識 & 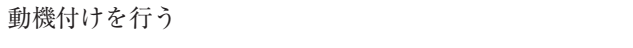 & & & \\
\hline & & 意識 & キーパーソンの認識レベルに合わせて情報提供する & & & \\
\hline & & 行動 & キーパーソンへ困りごとを尋ねる & & & \\
\hline & & 行動 & キーパーソンに率直にニーズは何か尋ねる & & & \\
\hline & & 行動 & キーパーソンから質問したくなるような質問をする & & & \\
\hline & & 行動 & キーパーソンにニーズを明確にするための教育をする & & & \\
\hline & & 行動 & 企業のミッション・重点課題を確認する & & & \\
\hline & & 行動 & ニーズの見える化に必要な資源を提供する & & & \\
\hline & & 行動 & キーパーソンからニーズ仮説の裏付けをとる & & & \\
\hline & & 行動 & 健康関連の会社の方針・目標づくりを促す & & & \\
\hline
\end{tabular}


Table 3c. 分析されたカテゴリ（2-3．産業医の介入に関する補足要素）

\begin{tabular}{|c|c|}
\hline \multicolumn{2}{|r|}{ 産業医介入に関する補足要素（2-3） } \\
\hline \multicolumn{2}{|r|}{ 1）共有される情報 } \\
\hline \multirow{9}{*}{ 社外情報 } & （特に共通項のある）他社の事例・取り組み・傾向 \\
\hline & 世間で話題になっている直接関係のない他社の事例 \\
\hline & 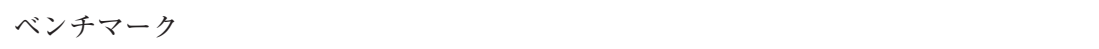 \\
\hline & ストレスチェックに関する法的情報・他企業の動向 \\
\hline & 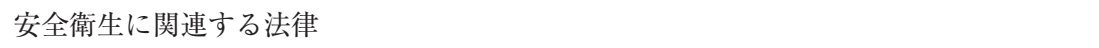 \\
\hline & 一般的な産業保健活動の目安 \\
\hline & 学術情報 (産業保健・臨床医学) \\
\hline & 健康関連の社会ムーブメント \\
\hline & 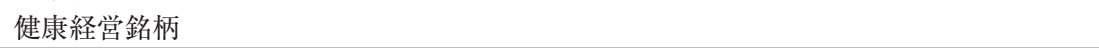 \\
\hline \multirow{22}{*}{ 社内情報 } & 労働者の身体的な健康（健診有所見・精密検査受診率／就業管理・発生者数 /個別事例) \\
\hline & 労働者の精神的な健康（就業措置・発生者数／個別事例） \\
\hline & 社内のストレスチェック結果 \\
\hline & 労働者の生活習慣 \\
\hline & 労働者の生の声 \\
\hline & 過重労働関連 \\
\hline & 健康関連休職 · 死亡状況 \\
\hline & 労災 \\
\hline & 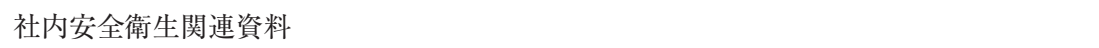 \\
\hline & 産業保健活動・施策実施状況（健診含む） \\
\hline & 各種面談結果 \\
\hline & 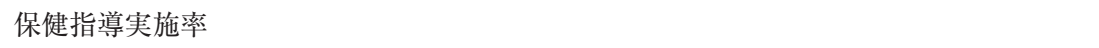 \\
\hline & 物理的な職場環境の評価（温度等） \\
\hline & 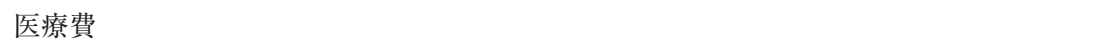 \\
\hline & 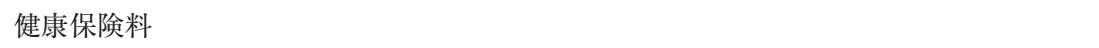 \\
\hline & 労働者の健康課題（現在・将来） \\
\hline & 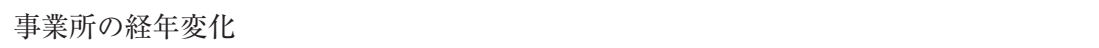 \\
\hline & 健康投資の費用対効果 \\
\hline & 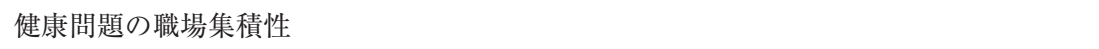 \\
\hline & 社内各事業所間の差（事業所ごとの費用面も含む） \\
\hline & 社内でのトピック \\
\hline & 社内での事故・事件 \\
\hline \multicolumn{2}{|r|}{ 2）接触場面 } \\
\hline \multirow{4}{*}{ 労働者・現場との場面 } & 面談·保健指導時 \\
\hline & 健康診断の問診時 \\
\hline & 職場巡視・訪問時 \\
\hline & 健康講話時 \\
\hline \multirow{8}{*}{ キーパーソンとの場面 } & 年度の活動評価・計画立案時 \\
\hline & キーパーソンが集まる会議 \\
\hline & 産業保健活動（既存）に関連する打ち合わせ時 \\
\hline & 職場巡視・訪問時（会社側スタッフの職場訪問時も含む） \\
\hline & 社外での接触時 \\
\hline & 社内事例対応時 \\
\hline & 本人への保健指導時 \\
\hline & 業務依頼を受ける時 \\
\hline \multicolumn{2}{|r|}{ 3）産業医介入の阻害要因 } \\
\hline \multirow{4}{*}{ 共有していない情報 } & 別部門を介して得る情報 \\
\hline & 調査に手間がかかる情報 \\
\hline & 個人情報の加工が難しい情報 \\
\hline & 調査する優先順位が低い情報 \\
\hline \multirow{3}{*}{ 阻害要因 } & 会社側の認識（問題や産業保健との関連性）不足で情報が入らない \\
\hline & 産業保健職側のマンパワー不足 \\
\hline & 会社側の健康問題に関する全般的な関心やへルスリテラシー不足 \\
\hline
\end{tabular}


以下,【】大項目，《》は中項目，〔〕は小項目（カ テゴリ）を示す。「」内の斜体はカテゴリ内容を補足す る実際のインタビュー内容の一部である。「」内の…は 省略を意味する。

2-1. 社内健康施策の意思決定プロセス

【社内健康施策の意思決定プロセス】の中項目は各組織 成員の意思決定要素となる《キーパーソンの意思決定へ の影響因子》と組織的意思決定要素となる《キーパーソ ンとの合意形成》《承認形式》《キーパーソンを決定する 影響因子》《キーパーソンとの関係性への影響因子》の 5 項目に整理された.

1）キーパーソンの意思決定への影響因子

〔経営者の価值観・企業のポリシーやミッション〕、〔意 思決定者・身近な人の健康問題に関連するテーマ〕，〔扱 う課題テーマの種類・規模〕、〔社内外で発生した事例の 距離感」という意思決定者らの事実的要素と価值的要素 がプロセスに影響を与えていた。

「経営者のスタンスとか思いみたいなものがはっきりし てる場合とはっきりしてない場合で施策のための決定 プロセスがだいぶ変わる」(J：製造業産業医)

「たまたまなんですけど副工場長に大腸癌のカメラやっ てきなって紹介状出したらたまたま引っかかったんで, それが今工場の中でブームになっていて・ドック受け させたりとかっていうような流れにはなってますね.」 $(D$ : 産業車製造業産業医)

\section{2）キーパーソンとの合意形成}

〔身近な利害関係者との合意形成〕〔所属事業部・事業 所責任者との合意形成〕〔安全健康管掌役員との合意形 成〕〔関連部署との合意形成〕〔労働組合との合意形 成〕，〔意思決定者との合意形成・承認〕といった集団的 合意形成が必要であり，キーパーソンが複数存在する企 業が多数であった。

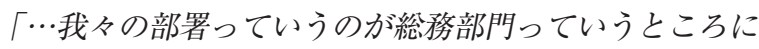
入っているので，そこのまず安全衛生課の課長に見て もらって, それから総務部長にいって」(B：電子部品 開発製造業産業医)

「私たちの方で企画してそれを安全環境推進部にプレゼ ンをしてダメであれば戻されて，それを何回か繰り返 して」(D:産業車製造業産業医 $)$

「総務部の担当取締役がいるので，彼が今常務でいるの でそこを落としたらほぼほぼ決まるんですね.」（G： 鉄道業産業医)

「それ (会議) には労働組合の方も来られていて結構 様々な意見があって，結構そことかの反発とかもある と通らないっていう話は伺いますね.」(E：製鉄業産 業医)

3) 承認形式

〔協議・審議を目的とした会議で最終承認〕、〔報告を目
的とした会議で最終承認〕といった〔合議制】の場合と， 〔複数単独執行制】，〔会議前に実質的に承認済み〕、意思 決定者との直接交涉で最終承認】されるような個人決定 の場合があった

会議体は安全衛生委員会やそれに代わる会社独自の委 員会, もしくは部長会議や経営会議など産業保健に限定 しない既定の会議が設定されていた，承認を得るまでに 複数の会議体をもつ企業もあり, 会議では前述の合意形 成を必要とする所属事業部・事業所責任者や労働組合, 意思決定者等複数のキーパーソンが参加していた.

「○○(会議名）っていう会議があるんですが, メン バーは会社側と労働組合側と，あと産業医の主だった 者がでて，そこで健康施策が決まるっていうことが多 いです.」(I：電機機器製造業産業医)

「安全と環境, 健康もやっているところにプレゼンをし てダメであれば戻されて，それを何回か繰り返してあ る程度煮詰まったところで事業所, 工場長の方にプレ ゼンに行って，そこでまたやりとりをして $G O$ サイン がでたらっていう形ですね.」( $D$ : 産業車製造業産業 医）

「一応経営会議で取締役会のところで説明をしてそこの ところで承認を得るって形なんですけどその前でほぼ 決まる形になってます.」(G：鉄道業産業医)

4）キーパーソンを決定する影響因子

〔意思決定プロセスが決まっているか否か〕、〔承認機能 をもつレイヤー (経営層か否か)], 〔産業保健職自身の所 属の差（健保兼務等），〔勤務場所（本社と支店／エリ ア / 系列会社)]，〔資金源（事業所 /工場 / 本社 /支 店)〕，〔労働組合の有無〕という組織体制によってキー パーソンの範囲に差が生じていた。

「健保と産業保健スタッフと常にミーティングしてるか ら基本なんかもう，兼務なんですよ，所属が.」（H： 精密機器製造販売産業医)

「(系列会社と) 本体はまたちょっと違う…(系列会社 は）事業所 1 個ですけど，事業所 7 個あるんでこのや り方で行くと収拾がつかなくなるんですよ.」(F': 自動 車製造・販売業産業医)

$\lceil う ち$ 労働組合がないので」 $(B$ : 電子部品開発製造 業産業医)

「全社の組合, 全社の会社側, 全社の産業医の主立った 人間の会議でなされてるってことですね.」(I：電機機 器製造業産業医)

5）キーパーソンとの関係性への影響因子

〔意思決定者へのアクセスのしやすさ (距離等)], 〔最 終的な承認の場に介入するか否かといった企業ごとの 組織構造・体制が，キーパーソンとの関係性に影響して いた。

「本社の場合は建屋っていうか場所が違うんですけど. 
うちの場合は同じところにいるので，まあぶっちゃけ 取っ捕まえることができると，仧の辺プラーっと歩い てたら，ちょっとといったことを.」(F：自動車製造・ 販売業産業医)

2-2. 産業医の介入（要素と具体的な方法）

意思決定を円滑に進めるために【関係性の構築・相互 理解の促進】といった日頃の土台づくりと，それとは別 に特定の施策展開に向けて, 企業内の意思決定の構造を 踏まえた【根回し・調整】、【仮説に基づいたニーズの可 視化】，ニーズを企画に反映させた【統合的な企画づく り・提案】にかけて介入がなされていた.

1）関倸性の構築・相互理解の促進

【関倸性の構築・相互理解の促進】は《接触機会の獲 得》《信頼性の保持》《活動や課題の共有》の 3 つの中項 目に整理された。

（1）接触機会の獲得

常時必要とされる意識または行動として〔キーパーソ ンと頻回に接触機会をもつ】が挙がった.

接触機会を増やすために〔業務外 (宴席等) でのコ ミュニケーション〕〔キーパーソンと人を介さず連絡を とる (メール・手紙・電話等) 〕 〔キーパーソンの活動に 同行する〕, 〔産業保健活動以外の社内活動に参加する〕, 〔キーパーソンに直接会いに行く〕，〔こまめに新たな情報 を伝えに行くるといった手法を用いていた.

「社長とはしょっちゅう会いに行きます。・而しょっちゅ う小ネタを見つけては「ちょっと報告に行きたいんで すけれど」って言って.」(F: 自動車製造・販売業産業 医)

「(キーパーソンとのやりとりをスムーズにするために は?）飲みニケーションのような気がする.」(H：精 密機器製造販売産業医)

「うちの事業所特有ですけど課外活動が非常に多いので そこで話すことも多いです.」( $A$ ：化学工業産業医)

(2) 信頼性の保持

常時必要とされる意識または行動として〔キーパーソ ンとの活動内容・状況の相互理解〕〔キーパーソンとの 信頼される関係性を構築する〕，[心理的距離を縮めるよ うに関わる〕，〔キーパーソンのキャラクターに合わせて 関わる]など拉互いに理解し合い，歩み寄る関わりを意 識していた。

信頼関係を築くために, 〔活動に対して第三者からの良 い評価を得る〕，〔活動を後押しする仲間を増やす〕， 〔キーパーソンに手柄を渡す〕，〔日頃から引き出しを持 ち, 求められたときに期待に応える〕、〔キーパーソンに 役に立つと思わせる (ポジショニング)], 〔産業保健職個 人に興味をもってもらううといった，相手や自身を魅力 的にみせる行動がとられていた，また，期待に応えるこ とに臨床的なニーズに対応するという意味も含んでいた。
「向こうが何をしているか知ってるし，向こうもこっち が何をしてるかわかってるんで，別組織っていう感じ があんましないです.」( $H$ : 精密機器製造販売産業医) 「よその会社の方がやっぱりこっちが頑張っていること を言ってくれたりした部分が最初ありましたね.」 $(G:$ 鉄道業産業医)

「各職場の管理職の方や衛生管理者の方を卷き込んだ会 議, 説明会, 話し合いの会をつくってそこで説明をし ていって. 表彰もされたから,「ほらみんなのおかげで 表彰されました」っていったら, みんなだんだん調子 に乗って，…仲間がね，できてきたんです.」( $G$ : 鉄 道業産業医)

（3）活動や課題の共有

常時必要とされる意識または行動として〔問題意識を 持たせる・方向性を合わせる」といった発言がみられた．

共有するための具体的な方法では〔施策に関連する背 景や経過を段階的に伝える（布石を置く）、〔キーパーソ ンと一緒に考える機会をもつ〕、〔キーパーソンと成功体 験を共有する]のように, 頻回に意思決定者やキーパー ソンと関わり, 一連の活動に巻き込みながら成功体験を 共有していた．また〔活動状況をキーパーソンと共有で きる既定の場・時間を利用する】という共有場所の存在 も関係性に関わる要素であった。

「「最近どうですか」みたいな会話をずっとしていると， その中で「「ちょっと残業多くて参ってる人多いです 权」ってじゃあ「あそこのこの部門でしょ」って… ずっとしてたりすると, こういう方法がある、こうい う材料があるんですよ，こういう研究会があるんで 行ってきたいです，で行ってきたらこういうのがあり ましたっていうような日常の話の流れになりますね.」 $(I:$ 電機機器製造業産業医)

「人事部長とは毎月 1 回会っているので, (月 1 回)以 上あるので」( $G$ : 鉄道業産業医 $)$

2）根回し・調整

【根回し・調整】は《環境をつくる》《人を掞さえる》 に整理された。

（1）環境をつくる

常時必要となる意識または行動は〔やらざる得ない環 境を整える（外堀を埋める）」にまとめられた.

環境づくりの具体的な行動は〔新たな会議体の設定で 介入機会を増やするに整理された。

「意識付けをやりながら一方でアンケートをとったりし て，何というか外堀を理める，やらなきゃいけないん だなということのある意味圧力と」( $\mathrm{J}$ : 製造業産業医 $)$ 「話し合いの公式な場をつくった方が良いだろうという ことを申し上げて…それで会社のそこに集まろうと.」 $(F$ ：自動車製造・販売業産業医) 
（2）人をおさえる

常時必要となる意識または行動は〔会社の承認ルート

（人）を把握する】が挙がった.

人をおさえるための具体的な行動は〔関連部署・関連 事業所を調整する (説得含む)]，〔会議前段階にキーパー ソンへの根回しを行う〕，〔通常業務以外の社内活動に参 加して顔を売る〕に整理された。

「社長のところへ裹工作にロビー活動をして，で自分た ちの直接の上司は人事総務部の本部長なんで, そこと こうやっといてから最後副社長会でどかんとやる.」

$\left(F^{\prime}\right.$ : 自動車製造・販売業産業医)

「健保のそういった会議で 1 回 2 回行ったんですよね. そしたらあっちも興味持ってくれたからすごい嬉し かったし，“産業医が参加することがまずなかったの で，すごく喜んでくださって，いろんなデー夕をすご くくれやすくなりましたね.」(G：鉄道業産業医 $)$

3）仮説に基づいたニーズの可視化

【仮説に基づいたニーズの可視化】は中項目《ニーズ仮 説》と《ニーズの可視化》の 2 項目に整理された.

(1) ニーズ仮説

ニーズ仮説は労働者・現場との関わりとキーパーソン との関わりに分類された.

(1)労働者・現場との関わり

常時必要とされる意識または行動として〔労働者と接 点を持つ時には常に意識する】といった発言があった.

ニーズ仮説を立てるための具体的な行動として，〔産業 保健活動で対面した社員の反応をみる〕，〔労働者から直 接受けた要望から推測する」といった労働者から直接情 報を得る方法がみられた。また，〔産業保健職の現場感か ら推測する〕，〔健診問診データから推測する〕，〔社内イ ベントに参加して情報収集する〕，〔組合からの情報から 推測する〕といった間接的な方法がみられた。

「普段の面談で，社員から聞く声をいろんな声を面談の 中で仕事に関する話っていうのは心がけてしてもらう

ようにしている」(B：電子部品開発製造業産業医)

「メンタル対応していたりとか, 長時間 (労働) の対応 をしていたりだとが...そういう面談とかを通じての意 見とか現場の感覚ですね.」(I：電機機器製造業産業 医)

「所属している総務組織とかあとは連携のある人事組織 とか他の組織でもいろんなイベントに呼んでもらった りとか，会社の大きなイベントもあったりするので,

そういう場面でのコミュニケーションを大事にしてい る」(B: 電子部品開発製造業産業医)

(2)キーパーソンとの関わり

常時必要とされる意識または行動として, 意思決定者 やキーパーソンが〔興味がないものも注目して分類する〕 が挙がった.
ニーズ仮説を立てるための具体的な行動では，〔キー パーソンから直接くる要望や質問から推測する〕、〔キー パーソンとの日常会話や会議等での指摘から推測する], 〔キーパーソンの活動に同行する〕，〔キーパーソンの部下 から聴取する〕, 〔情報共有・企画提案後のキーパーソン の反応をみる]といった言動から推測する・周辺から聴 取する関わりがあった。

「説明に行くときに必ず質問でこれはどうなの？ってい うのが最初の 1 年間の, 着任して 1 年間で毎回聞かれ るのでそこをおさえないとこの会社は進まないんだ なっていうのがわかりました.」(A：化学工業産業医) 「毎日所長とか副所長のパトロールが毎朝早朝パトロー ルという形であるので，そのときに産業医も同行させ ていただくので, そうした場も経営層の方の交流する 機会にもなりますし，ニーズとかも把握できる機会に なっているんじゃないかと思います.」（E：製鉄業産 業医)

「他の課長とかからも，そういえばこんなこと言ってた とか.」(G: 鉄道業産業医 $)$

(2) ニーズの可視化

【ニーズの可視化】は《労働者・現場との関わり》と 《キーパーソンとの関わり》に整理された.

(1)労働者・現場との関わり

ニーズを可視化するための具体的な行動として〔労働 者との接触時に困りごとを尋ねる】，〔現場から業務の依 頼を受けた時にヒアリングする〕、職場上司・衛生担当 者から情報収集する〕，〔アンケート調査をする〕といっ た直接聞く・関係者から裏付けをとるという手法が挙 がった。

「健診のときに保健指導も一緒にやるという形になって いて30分程度保健師さんの話をするという流れになっ ているので，そういったところでも（困りごとなど） ヒアリングももちろんしていると思います.」（E：製 鉄業産業医)

「時々健康講話であったりとか研修の依頼がある場合が あるのでそういった中で従業員の方の声をキャッチす ることはあります.」(A：化学工業産業医)

「その上の人と長時間残業面談をしたときに何か他に 困っていることないですか?っていうようなイン夕 ビューはします.」(D：産業車製造業産業医)

(2)キーパーソンとの関わり

常時必要とされる意識または行動では，〔動機付けを行 う〕，〔キーパーソンの認識レベルに合わせて情報提供す る]ことでニーズの可視化を図っていた.

ニーズを可視化するための具体的な行動としては, 〔キーパーソンへ困りごとを尋ねる〕，〔キーパーソンに率 直にニーズは何か尋ねる〕、〔キーパーソンから質問した くなるような質問をする〕，〔キーパーソンにニーズを明 
確にするための教育をする〕，〔企業のミッション・重点 課題を確認する〕，〔ニーズの見える化に必要な資源を提 供する〕，〔キーパーソンからニーズ仮説の裏付けをと る], 〔健康関連の会社の方針・目標づくりを促す〕と いった直接尋ねる手法のほか，スタンスを理解する，可 視化に必要な資源や方法を提供する, 周辺から裏付けを とるといった介入手法が挙がった.

「思いがないところとかミッションとかポリシーがはっ きりしてない部分っていうのが，まず細かい施策の前 にそういうことをやったほうが良いということの動機 付けをやるっていう活動がメインになりますよね.」

$(J$ : 製造業産業医)

「今 (の担当者) はウォンツが分かりづらくって逆に こっちが教育中だったりもするんですけど...」(G：鉄 道業産業医)

「各所でみんなで目標作って，「頑張りましょう」って 言っていったら，仲間になっていって，その結果でう ちらはあんまり動いてないんですけどなんか勝手にす るようになっていっちゃって.」(G：鉄道業産業医)

4）統合的な企画づくり・提案

【企画づくり・提案】は中項目《統合的な企画づくり》 《統合的な企画提案》の 2 項目に整理された.

(1) 統合的な企画づくり

常時必要とされる意識または行動として，〔日頃から引 き出しを準備する〕といった日頃の企画の準備と〔情報 を視覚化する〕，〔文書でまとめる〕といった分かりやす い資料づくりが挙がった。

特定の施策に向けた具体的な行動として，〔費用面も含 めて年間計画を立案する〕，〔外部の情報を活用して施策 をつくる〕，〔予算の範囲内で有効な施策をつくる〕, 〔徐々に目標を上げる〕といった工夫が見られた。

「こちらでいくつか引き出しをもっておいて，で全く やってない状況だとなかなか説明が難しいので, それ ぞれを少しずつ動かしてるというような状況の時に例 えばそういう外的要因がどんどん入ってくるとそれで シュッと進める.」( $\mathrm{J}$ : 製造業産業医 $)$

「こういうことが会社にとって課題になっていて必要だ から私たちとしてはこういう風にしたいと，そのため にこれだけのお金が必要ですっていうものを，…毎年 立てて」(B: 電子部品開発製造業産業医)

「外からの情報を活用してそれをもとに施策をつくって いくという風な形に今はなってます，例えば他社の事 例であるとか学会での広報であるとか」(J：製造業産 業医)

(2) 統合的な企画提案

常時必要となる意識または行動として,〔根気強く企画 を提案し続ける〕，〔企業全体にとってのメリットを伝え 後押しをする」といった関わりが挙がった.
特定の施策に向けた具体的な行動として, 〔社内外の動 きと関連づけた案を提示する〕，〔施策に関するプレゼン テーションを行う〕、〔聴取したニーズと分析データを併 せて提示する〕，〔ニーズに適した資源を複数提案する〕, 〔トライアル施策を提案する〕，〔公平性を利用して施策展 開につなげる〕という方法が挙がった。

「健康施策‥プラス何か会社の我々のニーズではない何 か会社の経営的なコスト的な何かにそこに合致したか らうちは上手くいっただけだと思ってます.」（F：自 動車製造・販売業産業医)

「ある程度 (従業員の声) まとまってきたら「ここのと ころはこうなってますね」じゃなくて「ここのとこ ろって今どんなですかね？」とかって聞いたりとかし て探って，で上からは情報もらった上で加工したもの を数字とかに出てきたらそれを届けるみたいなそんな 感じのことをしているんですよね.」（G：鉄道業産業 医)

「(新たに建つ工場の契煙所を外に出すので，既存の工 場も外に出す）そうじゃないと公平じゃないよねって いうやり方はしました」（F：自動車製造・販売業産 業医)

2-3. 産業医の介入に関する補足要素 企業の意思決定に向けた産業医の介入において, キー パーソンとの間で【共有される情報】が存在し, 情報を 活用しながら, 様々な【接触場面】において介入がなさ れていた。 また，状況により共有されない情報があり， その背景には【産業医介入の阻害要因】が関係していた. 1）共有される情報

【共有される情報】は中項目《社外情報》と《社内情 報》の 2 項目に整理された.

なお,この項目はインタビュイーの回答内容が主に情 報の列挙であったこと, カテゴリ数が多いことからイン タビュー内容を割愛した。

（1）社外情報

〔(特に共通項のある) 他社の事例・取り組み・傾向〕, 〔世間で話題になっている直接関係のない他社の事例〕, 〔ベンチマーク〕，〔ストレスチェックに関する法的情報・ 他企業の動向〕，〔安全衛生に関連する法律〕，〔一般的な 産業保健活動の目安〕, 〔学術情報（産業保健・臨床医 学) 〕, 〔健康関連の社会ムーブメント〕, 〔健康経営銘柄〕 といった社外情報から社内情報と比較できる価值基準と, 世間の常識・流れを把握していた。

（2）社内情報

〔労働者の身体的な健康（健診有所見・精密検査受診 率 / 就業管理 - 発生者数/個別事例) ], 〔従業員の精神的 な健康（就業措置 - 発生者数/個別事例)〕, 〔社内のス卜 レスチェック結果〕, 〔労働者の生活習慣〕, 〔労働者の生 の声〕, 〔過重労働関連〕, 〔健康関連休職 - 死亡状況〕, 
〔労災〕，〔社内安全衛生関連資料]，〔産業保健活動・施策 実施状況（健診含む)〕，〔各種面談結果〕，〔保健指導実施 率〕、物理的な職場環境の評価（温度等）〕，〔医療費〕, 〔健康保険料〕，〔労働者の健康課題（現在・将来），〔事 業所の経年変化〕，〔健康投資の費用対効果〕，〔健康問題 の職場集積性〕、社内各事業所間の差（事業所ごとの費 用面も含む)〕，〔社内でのトピック〕，〔社内での事故・事 件〕といった労働者の健康情報を数と個別事例で把握し ているほか, 社内産業保健活動状況や将来のリスクを想 定する情報, 経営に影響するコストなどを共有していた。 2）接触場面

【接触場面】は《労働者・現場との場面》と《キーパー ソンとの場面》に整理された。ここで取り上げられる場 面とは常時行われる介入および特定の施策展開への介入 場面双方に関連する場面である。

（1）労働者・現場との場面

〔面談・保健指導時〕,〔健康診断の問診時〕、職場巡 視・訪問時〕，〔健康講話時〕にカテゴリ化された。

「健診のときに保健指導も一緒にやるという形になって いて」(E：製鉄業産業医)

「保健師だけで時々健康講話であったりとか, 研修の依 頼がある場合があるのでそういった中で従業員の方の 声をキャッチすることはあります.」(A：化学工業産 業医)

（2）キーパーソンとの場面

〔年度の活動評価・計画立案時〕〔キーパーソンが集ま る会議〕、産業保健活動（既存）に関する打ち合わせ 時〕、職場巡視・訪問時（会社側スタッフの職場訪問時 も含む)], 〔社外での接触時〕, 〔社内事例対応時〕, キー パーソン〔本人の保健指導時〕に分類された.

「部長会議は先ほどお話した各事業所の中での部門長が 集まる会議ですので，そこで目的であったり，背景， 計画とどういった形でそれを評価するのかとか改善し ていくのかっていうところを話す場があります.」

(A:化学工業産業医)

「社長と飲みに行ったりとか.」(F：自動車製造・販売 業産業医)

「電車が一緒だったとか。...たたまたま会うことっていう のが結構あるんですよ.」( $G$ : 鉄道業産業医)

「個別事例の対応をしているときに合わせて話（要望） が出ることもありますね.」(A：化学工業産業医)

3）産業医介入の阻害要因

【産業医介入の阻害要因】は《共有していない情報》と 《阻害要因》に整理された.

（1）共有していない情報

〔別部門を介して得る情報〕，〔調査に手間がかかる情 報〕，〔個人情報の加工が難しい情報〕，〔調査する優先順 位が低い情報】に分類された。
「アブセンティーズム・プレゼンティーズムに関しては その情報を全部持っているのは人事なんですけど人事 課の方も…それまで情報が入りきれてないってところ があるんですよね.」( $G$ : 鉄道業産業医 $)$

(2) 阻害要因

〔会社側の認識（問題や産業保健との関連性）の不足で 情報が入らない〕、〔産業保健職側のマンパワー不足〕, 〔会社側の健康問題に関する全般的な関心やへルスリテラ シー不足〕といった会社側・産業保健職側の要因が抽出 された。

「医療費に関しては健康保険組合が主体となっていて… 統合もあった背景からなかなかそこの情報発信が十分 できていないところもある」(A：化学工業産業医)

3. カテゴリの信頼性

3 名によるカテゴリ分類への一致率は, $72.1 \%$, 79.2\%, 71.4\%であり, カテゴリが信頼性を確保している ことが示された。

\section{V. 考 察}

本研究では, 健康施策において企業の意思決定が円滑 になされるための産業保健活動の要素・具体的な方法を 検討した. その結果, 社内健康施策決定の意思決定プロ セス, 産業医の介入, 産業医の介入に関する補足要素の 大きく 3 つの要素に整理され, 企業の意思決定段階に 沿った産業医の具体的な介入の実態が明らかとなった。

\section{1. 結果に基づく考察}

結果に基づき, 一般的な企業組織の意思決定との共通 点および産業保健において強調される点や特徴を中心に 考察する。

1）社内健康施策決定プロセスの特徵

施策決定プロセスの実態から, 社内健康施策決定プロ セスは組織内成員の意思決定と組織環境によって形成さ れた意思決定プロセスが複合し，成り立っていることが 示唆された，そのため，2つの側面を考慮した産業医の 介入が求められるであろう.

（1）産業保健における意思決定者を中心とした組織成員 の意思決定の特徴

企業のポリシーやミッションのような経営者の価值観 を含んだ企業全体の目標や, 扱う課題の種類・規模のよ うな実際の事案が, 意思決定者らの意思決定に影響を与 えていることが推測された.

一般的な企業組織の意思決定には Barnard ${ }^{18)}$ が定義し た組織の成立・存続の条件にも組織目標が含まれており, 産業保健分野でも, 組織目標が組織成員の意思決定に必 要な要素と捉えられる. また, 経営者の価值観を含む企 
業全体の目標や扱う事案は, $\operatorname{Simon}^{1)}$ が示した, 意思決定 を下す前提となる決定前提に当てはまると考えられ，産 業保健の意思決定においても重要な役割を果たすと考え られた。

産業保健特有の意思決定では, 経営者もしくは権限を 委譲された意思決定者に対し産業医が専門家として関与 していることが示された。 つまり，キーパーソンの決定 前提に産業医が関与することで，企業の意志決定を促進 させると推測される。永田 ${ }^{19)}$ の仮説には，産業保健に関 する経営者の意思決定プロセスには安全衛生情報から経 営情報への翻訳が含まれているとされている，産業医は この翻訳のプロセスに貢献し，意思決定者が意思決定し やすい情報に変換する役割を担っていると考えられる.

なお，公式の意思決定者とは別に実際の意思決定に大き な権限を持つ者は, 企業ごとで職位が様々であった。 そ の背景として, 所属部門など産業医の組織内での所属の 違いや, 本社や支店など産業医の活動拠点の差, 施策展 開に用いる資金源の違い，企業が設定している承認機能 をもつレイヤーの違い等, 企業の環境, 体制が影響して いることが考えられた，インタビュイーによっては，社 内統括産業医が意思決定関与者となるケースもあり，産 業医の職位によってもキーパーソンが異なることが推測 された.よって施策決定を円滑にするには, 本研究で形 成されたカテゴリをもとに企業を診断し，どの職位に実 質の権限が与えられているのか, 更には職位ごとの影響 力はどの程度であるかを見極めることが重要であると考 えられる。

（2）産業保健における組織的な意思決定プロセスの特徵 前段階として産業医が複数のキーパーソンや実施に影 響のある関連部署との合意形成を行っているケースが殆 どであった，合意形成が必要な範囲は，産業保健の特徵 である他部門との調整や, 労働者のニーズ把握に繋がる 労働組合まで及んでいた，実際の承認形式も，複数の キーパーソンと段階的もしくは同時に合意をとり承認を 得るシステムとなっていた。 また, 一部の企業では, 会 議前に実質承認されているという実態が明らかとなった. 更に，本社から遠方の地域では意思決定者がエリアの トップであるケースが多く，本社と比べ意思決定までの 手続きが簡素である傾向が見られた。 また，小〜中規模 の事業所の産業医である場合に最終的な意思決定段階に 関与できる傾向にあった. 加えて, インタビュイーに よってはキーパーソンに統括産業医が含まれる者もいる ことから，産業医自身が統括的な役割をもっている場合 や企業規模が小〜中規模の場合は意思決定プロセスが短 縮される可能性が示唆された。

産業保健における組織的な意思決定プロセスが一般的 な組織の意思決定と同様であるのは, 承認形式について, 日本の特徵としてあげられた集団的合意形成が必要とさ
れるという点である. 加藤 ${ }^{20)}$ や中村 ${ }^{21)}$, Abbeglen ${ }^{22)}$ に よって特に日本企業は集団的合意形成の傾向が強いこと が示されている. 清水 ${ }^{12)}$ の組織での意思決定プロセスを 分類した研究と比較すると日本企業で多く見られる「全 会一致型」に近い形式が中心であり，本研究の結果は日 本企業での通常の意思決定と類似していた，一方，会議 前に承認されているという実態は先行研究では見られな かったが，集団的合意形成を補完する手続きと捉えられ る。また産業保健においても意思決定者と物理的距離が 近いことは, 意思決定を進めるうえで有利に働くことが 考えられた. Simon ${ }^{1)}$ は意思決定者と場所的に近いこと は, 口頭のコミュニケーションの頻度を決める要因とし， 物理的距離は接触機会の設定に大きく影響すると予測さ れる。

産業保健特有の実態としては, 合意形成を必要とする 範囲に他部門や労働組合が含まれていた点である。この 点は蔦木 ${ }^{5}$ の研究で産業保健専門職の介入において必要 だとされた関連部署との合意形成にあたると考えられる. そのため, 組合のニーズが汲まれる安全衛生委員会もし くは代替とする場を, 意思決定の場として有効活用でき るよう働きかけることが, 健康施策決定を円滑化する可 能性を高められると考えられる。 また, 産業保健専門職 自身の所属や, 労働組合の有無など各企業の実態に則し て合意形成の範囲が変わることが示唆され, 健康施策決 定プロセスの構造が, 企業によって多様である要因の一 つと推測される. 加えて, 専門職から提案し承認を得て いくプロセスは, 一般的な企業組織の意思決定に比べ特 殊な承認形式である. したがって, 最終的な意思決定に 影響するキーパーソンを，自身の所属や企業の体制をも とに把握するという介入前段階の準備が, 産業保健にお いて強調されるべきプロセスであると考えられる.

2）産業医の介入

(1) 関係性の構築・相互理解の促進

業務内外の活動を通した意識的な接触機会を利用して, キーパーソンと信頼される関係性を構築することや, 活 動状況の相互理解といった意思決定者らとの日頃の関係 性, 活動への理解の程度が意思決定に影響すると考えら れた。本研究のインタビュイーとなった産業医らは, 共 有する情報が, より有効に扱われるために, 前段階に意 思決定者との関係性を築く必要があることを認識し, 土 台づくりを行っていると推測された. また, その一環と して, キーパーソンと心理的距離を縮めるように関わる という意識や, 専門職として臨床的ニーズ等に対応し期 待に応えること, キーパーソンに手柄を渡す, 活動を後 押しする仲間を増やすという行動によって関係性を強固 にできることが推察された，その他，担当者やキーパー ソンのヘルスリテラシーを高める教育を行うことにより， 意思決定の選択基準を共有することや, ニーズを明確か 
つ可視化すること，施策に関連する背景や経過を段階的 に伝えたりすることによって, キーパーソンと産業保健 専門職のそれぞれの活動や方向性の相互理解に繋がって いることが示唆された，加えて，共有が必要な情報や技 法などの引き出しを，常に準備しておくことが重要であ ると考えられた。

一般的な組織的な意思決定と同様な部分は, 集団合意 形成に伴う, キーパーソンとの関係性の構築が重要視さ れるという点である。理的距離を縮める意識や手柄を

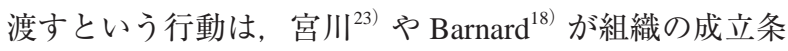
件の一つとして述べていた共通目標を達成するための意 欲の醸成に影響を与えていると推測される。また，活動 を後押しする仲間を増やすという行動は，非公式組織の 生成に繋がっていることが示唆された，非公式組織につ いて Simon ${ }^{1)}$ や Barnard ${ }^{18)}$ は，組織図に表される公式組織 とは対照に, 組織内で自然発生的に形成され, 組織全体 のコミュニケーションに影響を及ぼすとしており，産業 保健でも非公式組織の存在やその活用が窅えた。 そして 教育は, Simon $^{1)}$ の示すように, 決定の過程にある大部分 の参加者が, その組織と目標の一般像を共有することに 貢献している. 更に, 背景や経過を段階的に伝えること について, 今在 ${ }^{24)}$ は, 決められた過程の説明等により, 公正感や決定に対する受容的態度を促進することを指摘 しており，効果的な行動であると言える.

産業保健独自の注意点として, 土台づくりに扑てて, 相互理解のための活動がより重要となる点が挙げられる. 塚原 ${ }^{25}$ は，産業保健における活動が企業活動として有効 に展開されるために土台づくりが重要であると指摘して おり，結果を支持した内容となっている．土台づくりに 関係性の構築が含まれていることは, 蔦木5) の研究で事 業所の支援に信頼関倸の構築が必要と指摘された点と一 致している. また, 意思決定に意思決定者の決定前提が 影響する点は, 一般的な組織の意思決定と変わりないが, 産業保健に扔いては専門職とそれ以外の者との知識差が 大きく，産業保健に対する価值観が望ましい形となるよ う支援をする必要がある。そそのため，あらゆる意思決定 段階で, 教育や活動経過を段階的に伝える作業が求めら れると考えられる。井上 ${ }^{26}$ が, 人事労務が産業保健専門 職に求めることとして, 恒常的な情報提供を挙げており, キーパーソンのデマンドとも一致している. 意思決定の 基準を教育することは, 蔦木の研究で, 担当者の健康管 理への意識により事業所への健康管理状況が変化する ${ }^{5)}$ ことを示しているように，土台づくりの有効な手段と考 えられた。

\section{（2）根回し・調整}

会社の承認ルートを把握する, 関連部署・関連事業所 を調整する，審議・決定の前段階にキーパーソンへ根回 しを行うなど，根回しを重視する産業医も複数おり，意
思決定者を取り囲むキーパーソンの見極めやその者への 合意形成が円滑な意思決定へと慗がっていくことが予測 された。

一般的な組織の意思決定と同様である点は, 日本企業 の特徵である集団的合意形成 ${ }^{20-22)}$ を補完する根回しが, 有効に機能する可能性が高い点である. 井上 ${ }^{26)}$ は, 産業 保健専門職に求める交渉スキルとして根回しが必要とし ており, 本結果と共通している.

産業保健では, 活動の必要性に対する認識を高める作 業が必要なことから, 根回しの重要性は高いと考えられ る. 蔦木 ${ }^{5)}$ の研究においても所属機関内の合意形成への 介入が必要とされ, 本研究結果の根回しと, 概ね一致す る意味合いを持っていると捉えられる.

（3）ニーズ仮説に基づいたニーズの可視化

産業医は労働者やキーパーソンのニーズを可視化する ために, 両者のあらゆる接触機会から得られる日々の反 応を基にニーズ仮説を立てていくことが推測された，労 働者のニーズについては, 他の産業保健専門職の現場感 から推測するというように, 産業医のみでなく, 保健師 などから得られる情報も活用していることが窥えた。 キーパーソンに対しては，ニーズ仮説を立てるために キーパーソンの活動に同行することや，日常会話や指摘 から推測するなど社内外で接触機会を増やしていた，更 に意思決定者の言動などから, 価值観や産業保健に対す る認識をいかにもっているかについて探っていた.

そして立てられた仮説を基に, 更に意識的に介入機会 を持ち, 的を絞ってニーズの可視化を行っていることが 明らかとなった，労働者のニーズについては職場上司や 衛生担当者から情報収集することや，アンケート調査を することで集団としてのニーズを可視化する作業が行わ れていた。キーパーソンについては, 彼らの認識レベル に応じて情報提供することやニーズを明確にするための 教育をする, 動機付けを行うといった要素がニーズの可 視化を促進すると考えられた。

一般的な組織の意思決定との共通点は, 意思決定者の 価值観に注目している点である。一方, 産業保健におい て強調される点は, 活動が意思決定者や労働者らの健康 情報など, 個人的な部分への介入を必要とする点や, 労 働者のニーズが意思決定者のニーズに繋がる点, また, ニーズを可視化する課程で, 産業保健に対する認識がど の程度であるかを探る必要がある点, ニーズを知るため にもへルスリテラシーを高める教育や動機付けが必要と なる点である. 蔦木 ${ }^{5)}$ の研究でも事業所支援に必要なプ ロセスの一つとして動機付けを挙げており, 本研究と同 様の結果を得た.

（4）統合的な企画づくりと企画提案

日頃から臨床的なニーズなどに対応できるよう, 引き 出しを準備することでキーパーソンのニーズが高まった 
タイミングで提案ができるよう備え，更に社内外の動き と関連づけることや，企業全体にとってのメリットを伝 えることで動的なニーズに対応する工夫がなされていた。 また、ニーズに適した資源を複数提案するといった方法 が挙げられた。

一般の企業組織の意思決定プロセスと同様に, March と $\operatorname{Simon}^{11)}$ が唱える, 意思決定者が満足できる水準に基 づいて意志決定がなされている可能性が高く，産業医は キーパーソンが満足するポイントをニーズとして捉え, ニーズを基として情報を加工し，企画づくりと提案がな されていることが窅えた．企画提案には後述する経営の 視点が組み达まれていることも明らかとなった。

ただし，産業保健においては，企業全体にとってのメ リットを伝えるといった，産業保健としての課題を経営 情報に統合する必要性があると考えられる。これは考察 の組織成員の意思決定の特徵で記述した, 永田 ${ }^{19)}$ の安全 衛生情報から経営情報への翻訳と同義である.

3）介入の影響因子と補足要素

（1）共有される情報

産業医が社内外の情報をキーパーソンのニーズと経営 の視点を含めて加工し，共有をすることでキーパーソン の決定前提 ${ }^{1)}$ の形成を支援し，意思決定者が更に決定前 提に対応した情報や代替案を得ることでプロセスの円滑 化に繋がると推測された。

(1)事実前提と価值前提へのアプローチ

整理されたカテゴリには，企業の健康関連のポリシー やミッションなど価值的要素と従業員の身体的・精神的 な健康といった心身の健康情報などの事実的要素が含ま れていた，共有される情報は，企業ごとに大きな差は見 られなかったが，意思決定者の対応として，質問をして 積極的に情報を確かめる場合と，受動的に情報を受け入 れる場合に分かれた。

挙げられたカテゴリは Simon ${ }^{1)}$ が述べる価值前提と事 実前提にあたり，企業組織の一般的な意思決定同様，価 值と事実双方の要素からのアプローチが有効であること が示唆された。また，企業の健康関連のポリシーやミッ ションは，宮川年) や Barnard ${ }^{18)}$ が示す一般的に組織に必 要とされる共通目標にも対応することが推察された.

そして産業保健に対する活動への認識を高めるために は, 価值的, 事実的要素へのアプローチが, 特に重要 であると考えられる. Royal Society for the Prevention of Accidents が発行する資料において, 労㗢衛生アドバイ ザーの Roger Bibbing ${ }^{27)}$ は, 経営者のなかには, 経営にお ける産業保健の重要性を低く捉える者がいるとコメント している. したがって, 経営者の認識を確かめながら, 意思決定の判断基準となる価值前提や知識などの事実前 提に踏み込み, 健康関連の経営者のスタンスを明確化す る支援も必要であると考えられる。
(2)経営の視点

経営層が産業保健活動に対し, 健康投資の費用対効果 など総合的なコスト面, ベンチマーク, 他社の事例や取 り組み・傾向などに着目しているとされる企業が複数存 在し, 産業医は経営層のニーズを汲み, 経営の視点を認 識した上で企業の意思決定プロセスに介入していること が明らかとなった。また実際に日常でのやりとりや意思 決定者らの活動に同行することで意思決定に関わる要因 を探索しており, 経営の視点を取り入れる機会となって いることが考えられる。

組織的な意思決定に関する先行研究において, 経営者 は井手野 ${ }^{28)}$ の研究では先行き見通し, 野村 ${ }^{29)}$ の研究では 外的な基準要素に基づいて意思決定を行うとされ, 結果 として示された費用対効果などの要素には, 先行きが包 含し, ベンチマークや他社の事例や取り組み, 傾向など は外的な基準要素に当たると考えられる.

産業保健の活動においても, 福田 ${ }^{30)}$ は経営側の価値に 注目すべきという主張を行っており, その視点は本研究 と一致している.

近年, 労働者の健康の維持・増進と会社の生産性向上 を目指す「健康経営 $\rfloor^{31)}$ が注目されている。企業戦略的 に従業員の健康増進活動を推進する企業も増えており ${ }^{32}$, 意思決定へと導く視点になりうると捉えられる.

（2）接触機会となり得る場面

労働者・現場については, 面談・保健指導時や職場巡 視時など, 通常の活動場面を接触機会として捉えていた. キーパーソンについてはキーパーソンが集まる会議や社 内事例対応時など通常の活動場面に加え, 社外での接触 時のように活動範囲を限定せず，接触機会として活用し ている産業医も存在した。

産業保健サービスの特徵は, 面談や社内ルールの整備 を通して労働者や意思決定者に関与することが基本であ り，介入できる機会が多いことである．労働者・現場・ キーパンソンのいずれが対象であっても, 主たる目的に 固執せず，全ての意思決定段階において介入の全体像や 見通しを想定し，あらゆる場面を有効活用していくこと が最終的に円滑な組織の意思決定に繋がることが想定さ れた。

（3）情報共有における産業医介入の阻害要因

実際に別部門を介して得る情報を共有していないケー スや, 会社側の認識不足で情報が入らないなどコミュニ ケーションやマンパワーの問題が見られた.

産業保健サービスでは，健康情報などの個人情報を取 り扱うことから, 企業が活動を専門職に委ねる場合も少 なくない，実際の活動が見えにくいことから，会社側の 産業保健に対する理解が深まりにくいことが問題点とし て挙げられる。そのため, キーパーソンの産業保健に対 する認識を高めるには, 産業医をはじめとした産業保健 


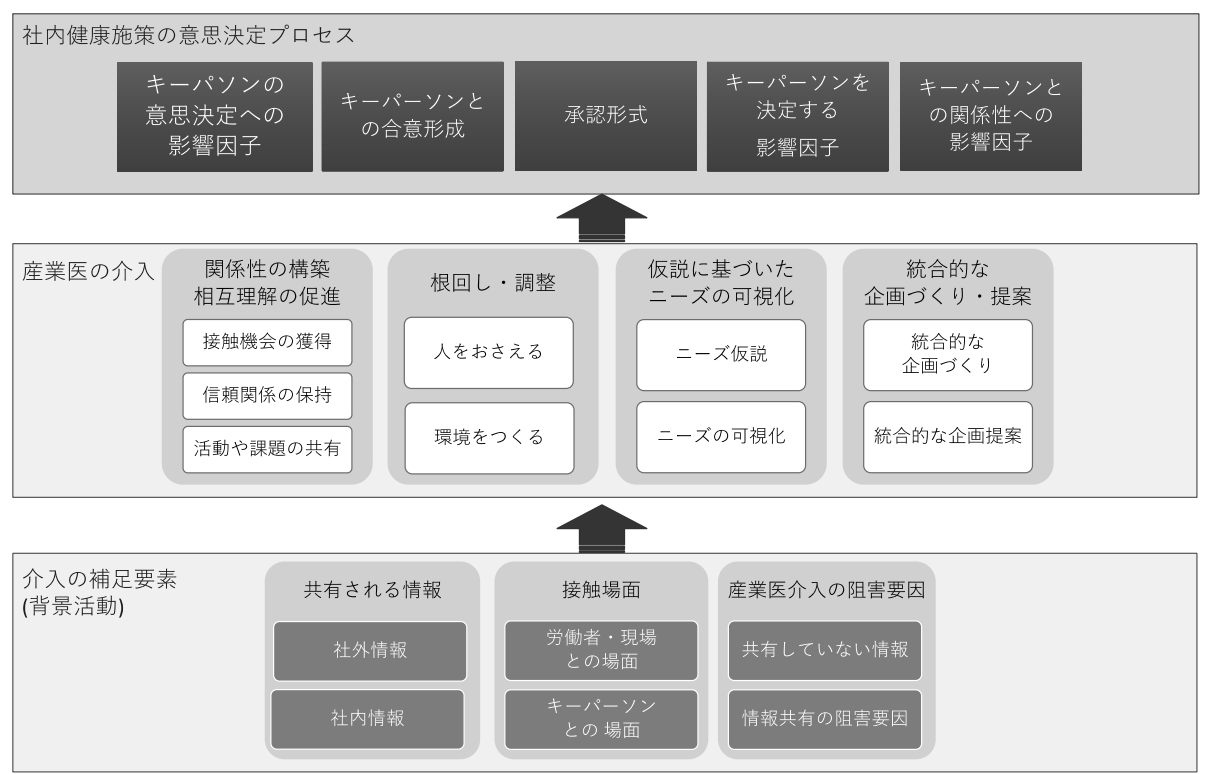

Fig. 1. 図解化された各カテゴリ

専門職からの意識的な働きかけが必要となるであろう. 対処法としては, 前述した担当者の教育や相互理解への 活動, 根回し, 非公式組織 ${ }^{1,18)}$ の活用および後述のチー ムでの介入が考えられる.

\section{2. カテゴリの図解化と解説}

各カテゴリを考察した結果，図解化したものが Fig. 1 である。

社内の健康施策の意思決定プロセスにおいて，意思決 定の構造に結びつく要素は,「キーパーソンの意思決定へ の影響因子」,「キーパーソンとの合意形成」,「承認形 式」,「キーパーソンを決定する影響因子」,「キーパーソ ンとの関係性への影響因子」が挙げられた。更に，それ らの要素に応じて，意思決定の円滑化を図るために「関 係性の構築・相互理解の促進」,「根回し・調整」,「仮説 に基づくニーズの可視化」，「統合的な企画づくり・提案」 という視点をもって様々な産業医の介入が行われていた. また「共有される情報」，「接触場面」，「産業医介入の阻 害要因」といった介入に関連する補足要素も，意思決定 の円滑化に影響を及ぼす要素として整理された.

施策決定プロセスにおけるキーパーソンの意思決定へ の影響因子には，経営者の価値観，意思決定者や身近な 人の健康問題に関連するテーマ, 扱う課題テーマの種類 や規模，事例の距離感という要素があった．意思決定者 らに共有される情報はキーパーソンの前提に合わせ，経 営的な視点を持って加工されていた.

また，組織の意思決定においてはキーパーソンとの合 意形成や承認形式が企業ごとに異なっていた．合意形成 の対象範囲を決定する影響因子は, 意思決定プロセスの
構造化の有無, 組織の紐付けや承認機能を持つ立場, 労 働組合の有無，勤務場所や資金源といった要素であった。 介入を要すキーパーソンに対して, 人を把握しておくこ とや会議前に話しをして合意を得る，合意形成をしやす い環境をつくるといった根回し・調整がされており，公 式の意思決定プロセスを超え実質的な承認形式に合わせ て会議前に合意を得ておく等，先読みした行動が見られ た.

キーパーソンとの関係性への影響因子としてキーパー ソンとのアクセスの容易さや介入機会の多さといった要 素があり，関係性の構築のために接触機会を獲得する, 活動や課題を共有するといった相互理解を促すことで, 土台づくりがなされていた。 また, 関係性の構築はキー パーソンの決定前提を理解することにもつながっていた.

日々の活動からニーズ仮説を立て，教育や動機付けを 通してニーズを可視化し, 企画に反映させ, 意思決定者 の満足に繋がるように，決定前提を踏まえた統合的な提 案を行うことで円滑な施策決定プロセス促進に貢献して いた。 そして，決定前提には労働者のニーズが含まれて いる可能性を孕んでいた，組織における共通目標に対し てはニーズの可視化を通して目標づくりを促し，共通目 標達成への意欲の醸成は関係性の構築・相互理解の促進 といった方法で介入が行われていた. 目標と意欲を統合 するためには，前述の関係性の構築に関わる行動によっ てなされていた。また公式組織とは異なる組織内のコ ミュニティを利用し，広範囲の情報収集と仲間づくりを 行っていた. 
3. 施策決定における今後の展望

産業医は産業保健の専門家として組織の意思決定プロ セスに直接的に関与できる立場にあり，意思決定者の決 定前提自体に影響を与え得る。そして，経営における産 業保健の必要性について，キーパーソンの認識を高める ことにより，組織の意思決定が円滑に進むことが推測さ れる。また，産業保健サービスの性質からも，キーパー ソンならびに労働者へ関与できる機会は多い. そのため, 産業医としての専門的医学知識を活かしつつ，あらゆる 意思決定段階において戦略的な介入が可能となる. 介入 には，本研究で明らかとなった「関係性の構築・相互理 解の促進」，「根回し・調整」，「仮説に基づくニーズの可 視化」，「統合的な企画づくり・提案」に関わる具体的な 手法を, 企業の意思決定の構造や動きに合わせて臨機応 変に発揮することが望ましい。 なお，本研究で示したカ テゴリは，実際の産業医活動で行っている手法と照合す ることで, 企業内で意思決定者や関与者とどのように関 わるかという側面で，自己評価や改善に活用することが 可能であると考えられる。

ただし介入において産業保健専門職チームメンバーそ れぞれの強みは異なる。産業看護職の場合，情緒的な人 間関係を積極的に形成し，信頼関係へ発展させる特徵が ある よう ように, 産業保健専門職各々の役割や得意分野に 応じてチームで介入していくことが望ましい，産業医が 嘱託の場合では，産業保健師などが中心となり関係性の 構築や根回しを行い, 医学的判断は産業医が行うといっ た役割分担が有効となるであろう。したがって，産業医 はチーム内メンバーの強みを見極め, チーム全体のリー ダーシップをとりつつ介入を行っていくことが望まれる.

なお，チームが機能するには，産業医以外の担当者に おける産業保健活動に関する十分な理解，実践経験を有 する産業医の確保，人事・労務部門，管理職等との連携 が重要である ${ }^{33)}$ とされており，体制づくりのための土台 づくりも重要だと思われる.

\section{VI. 研究の限界}

今回の調査内容は産業医からの聴取のため, 意思決定 者の認識として論じるには限界がある。意思決定プロセ スに関しても，聴取した内容は産業医が把握している実 態であり，正確さに欠ける恐れがある。そして過去の実 際に行った施策を想定したインタビューのため, 実際の 介入方法の想起の程度に差異がある可能性がある. 加え て，インタビュイーの連想を優先し，自由度の高い質問 を設定したことから，インタビュイーとなった産業医が， 介入した企業の意思決定段階や介入の程度について言語 化した程度に差が生じたため, 詳細を正確に記述するこ とはできない.
調査途中での質問項目の追加やインタビュー時間の個 人差, カテゴリ数の多さから, カテゴリごとの相対的な 重要度は本研究では示すことができない. それに伴い, インタビュイーとなった産業医の実務経験年数によって, 具体的な介入手法の特徵が異なる可能性を孕んでいたが, 層化を想定した研究デザインではないこともあり, 結果 として示すことができない. また，インタビュイーが九 州地方に集中しており, 本社組織とは離れた一事業所内 での意思決定プロセスについて語る者も多かったことか ら, 組織内の産業保健専門職のポジションによっては, この結果が当てはまるとは限らない.

そして, 本研究では企業で健康施策を展開できている 産業医を対象とすることで，企業の意思決定を円滑化す る手法を探索することを試みたが，インタビュイーに よって語られた介入手法が, 実際に効果的であったかを 立証することは困難である。よって, 結果の妥当性を高 めるためには, 企業の意思決定者側への質的調査や, 結 果を用いた介入研究の実施, また, 新たな健康施策・体 制を導入・構築し, 当該施策の導入等に際して意志決定 者に働きかけた内容に絞って質問した場合に，本研究と 同様の結果が得られるか等, 多面的な視点から検証する 必要があると考えられる。しかし，インタビュイーと なった産業医の殆どは産業衛生専門医資格を有しており， 大部分は産業医活動に関する知識, 技術の到達度を客観 的に評価されている者から具体的な手法を調査できたこ とは, 本研究の強みである.

意思決定プロセスについては, 組織特徵から構造化を 目指すには更なる標本数が必要であると推測される。今 後は業種ごとにモデル化やそのモデルに対応して産業医 やその他産業保健専門職が, どのような介入を行うと企 業の意思決定が円滑化できるのかを検討する。

謝辞：本研究を遂行する上でインタビューにご協力いた だきました産業医の先生方に，深く感謝の意を表します.

利益相反自己申告：申告すべきものなし

\section{文 献}

1) Herbert A. Simon. Administrative Behavior, 4th Edition. New York: Free Press, 1997/桑田耕太郎訳. 経営行動 経営組織 に扔ける意思決定過程の研究. 東京：ダイヤモンド社, 2009:ii-498.

2）ジァンドゥーソップ. 産業保健マーケティング. 東京：中 央労働災害防止協会, 2004:22-139.

3） Jahng Doosub J, 橋本英樹, 古木勝也. 産業保健計画 - 立案 の実践理論その1-対象集団選択と需要調査に対する理論的 考察（OPST 研究報告その 2 )。産業医科大学雑誌 2013;18 (3) :193-201. 
4) Jahng Doosub J, 古木勝也, 橋本英樹. 産業医サポートシス テム（OPSS）の開発，一産業医サポートチーム（OPTS） 研究報告一. 産業医科大学雑誌 2013;18(3):185-192.

5）蔦木美穂，錦戸典子．総合保険組合保健師による事業所支 援プロセスおよび背景要因に関する研究. 日本地域看護学 雑誌 $2008 ; 10(2): 7-13$.

6）畑中純子, 高㠃正子, 畑中三千代. メンタルヘルス不調の 労働者支援に扔ける管理監督者との連携のための産業看護 職による関係形成の構造. 産業衛生学雑誌 2018;60 (3): $69-77$.

7）田澤美香代, 瀬戸美才, 横田京子ほか. 企業における健康 づくりのニーズアセスメント（第 1 報）。産業衛生学雑誌 1999;41特別号： 489.

8）福田 洋, 武藤孝司, 福渡 靖ほか. 企業における健康づ くりのニーズアセスメント (第 2 報)。産業衛生学雑誌 1999;41特別号 : 490 .

9）黑木直美, 宮下奈々, 日野義之ほか. 小規模事業場におい て良好実践を行っている事業者の産業保健ニーズに関する 質的調査. 産業衛生学雑誌 2009;51(5):49-59.

10) John Dewey. How We Think. Boston: DC Heath and Company, 1910/植田清次訳. 思考の方法. 東京: 春秋社, 1950:109-121.

11) March JG, Simon HA. Organizations. New York: John Wiley \& Sons, 1958／高橋伸夫訳. オーガニゼーションズ 第 2 版 現 在組織論の原点. 東京：ダイヤモンド社, 1977:175-179.

12）清水 馨. 最高意思決定機関の意思決定プロセスの再検 討（新しい世紀と企業経営の変革)。經營學論集 2000;70: 267-274.

13）ライオン株式会社. 従業員の健康管理の推進. [Online]. [cited 2018 Aug 20]; Available from: URL: http://www.lion. co.jp/ja/csr/employee/health/

14）ヤフー株式会社. 従業員の健康. [Online]. [cited 2018 Aug 20]; Available from: URL: https://about.yahoo.co.jp/info/ conditioning/

15）DENSO．社員の健康づくり． [Online]. [cited 2018 Aug 20]; Available from: URL: https://www.denso.com/jp/ja/csr/ sociality-report/employees/health/

16）花王. 健康づくり推進体制. [Online]. [cited 2018 Aug 20]; Available from: URL: http://www.kao.com/content/dam/sites/ kao/www-kao-com/jp/ja/corporate/sustainability/pdf/sustainability2018-031.pdf

17）舟島なをみ. 質的研究への挑戦第 2 版. 東京: 医学書院, 2007:40-79.

18) Chester I. Barnard. The Functions of the Executive. Massachusetts:
Harvard University Press, 1968／飯野春樹訳. 新訳 経営者の 役割. 東京：ダイヤモンド社, 1968:85-130.

19）永田智久. 産業保健活動に関する経営者の意思決定モデル, 日本ヘルスサポートシステムシンポジウム 状況報告. [Online]. 2011 [cited 2018 Aug 20]; Available from: URL: https://www.jshss.org/wp-content/uploads/2011/10/ GM006-5_presentation.pdf

20）加藤靖慶. 日本的経営/リーダーシップ. 工場管理 2013;59 (2):14.

21）中村健壽. オフィス環境の変化と禀議制度に関する一考察. 静岡県立大学短期大学部研究紀要 1996;10:107-119.

22) Abegglen JC. 21st-Century Japanese Management: New System, Lasting Values. London: Palgrave Macmillan, 2006 / 山岡洋一 訳. 新・日本の経営. 東京：日本経済新聞社, 2004:23.

23）宮川公男. 意思決定論. 東京: 中央経済社, 2005:40-328.

24）今在慶一朗. 手続き的公正要因としての説明責任と鄭重さ に対する中心的・周辺的認知処理の影響. 社会心理学研究 2015;31(3):184-192.

25）荘司榮徳, 古木勝也, 塚原照臣ほか. ヘルシー・カンパ ニーの実現：21世紀の企業の健康に携わる方々へ．横浜： バイオコミュニケーションズ, 2001;41.

26）井上 豊. 人事労務が産業看護職に求める上手な交渉スキ ル。産業保健と看護 2015;7(1):50-53.

27）労働安全衛生網領案. OS\&H,RoSPA,2001.4:54. [Online]. 2001 [cited 2018 Aug 20]; Available from: URL: https://www. jniosh.go.jp/icpro/jicosh-old/japanese/library/highlight/ rospa/2001/apr/OSH0104PS.htm

28）井出野元子, 杉村 優. ビジネスマンと情報（その 1)意思決定のための情報元を中心として一. ドグメンテー ション研究 1985;35(5) :235-248.

29）野村重信. 情報が意思決定過程に及ぼす影響について。 日 本経営診断学会 年報 1998;30:129-136.

30）福田 洋. 企業レベルのアドボカシー：産業保健活動から, ヘルスカンパニー・健康経営へのアドボカシー. 日本健康 教育学会誌 2015;23(3) :237-245.

31）経済産業省．健康経営銘柄. [Online]. [cited 2018 Aug 20]; Available from: URL: http://www.meti.go.jp/policy/mono_ info_service/healthcare/kenko_meigara.html

32）厚生労働省. 平成28年 労働安全衛生調查. 2016

33）厚生労働省. 事業場に扔ける産業保健活動の拡充に関する検 討会報告書. [Online]. 2010. [cited 2018 Aug 20]; Available from: URL: http://www.mhlw.go.jp/stf/houdou/2r9852000000 wvk2-img/2r9852000000wvof.pdf 


\title{
Occupational health physicians' interventions based on the decision-making process for corporate health policies and company-employee needs: An exploratory study
}

\author{
Natsumi Shinzato, Masako Nagata, Tomohisa Nagata and Koji Mori \\ Department of Occupational Health Practice and Management, Institute of Industrial Ecological Sciences, University of Occupational \\ and Environmental Health, Kitakyushu, Japan
}

Abstract: Objective: The topic of occupational health physicians' specific interventions for deciding on corporate health measures has not been researched. Such interventions are necessary in corporate decision-making and for considering the needs of the company and its employees. We examined the aspects and methods of occupational health services that facilitate corporate decisionmaking regarding health measures. Methods: We conducted semi-structured interviews with 11 certified occupational health physicians involved in the planning of health measures at 10 companies. Data were analyzed qualitatively and inductively using Berelson's content analysis method. Results: We divided 144 items corresponding to the research theme into three categories: organizational decision-making process in health measures, occupational health physician interventions, and complementary factors concerning interventions. The interventions were further categorized as follows: building relationships, promoting mutual understanding; consensus-building process, coordination; visualization company needs based on hypotheses; and integrated planning and proposals. The study identified specific intervention methods of each category. Discussions: Aspects and methods that facilitate decision-making in occupational health services were as follows: 1) understanding the scope of consensus formation and its impact based on the characteristics of corporate decision-making regarding health measures and premises of decision maker; 2) improving awareness about occupational health by consistently presenting information on occupational health, translating it to be necessary for corporate management. Occupational health professionals, mainly occupational health physicians, are expected to contribute to health policy decisions while utilizing the method clarified in this study.

(Sangyo Eiseigaku Zasshi 2019; 61: 141-158) 